\title{
TITANIUM-CONTAINING COAGULANTS FOR FOUNDRY WASTEWATER TREATMENT
}

\author{
E. N. Kuzin ${ }^{1}$, N. E. Kruchinina ${ }^{1}$ \\ ${ }^{1}$ D. Mendeleyev University of Chemical Technology of Russia (Moscow, Russia)
}

E-mail: e.n.kuzin@mail.ru; krutch@muctr.ru

\section{AUTHOR'S INFO \\ E. N. Kuzin, Cand. Eng., Department of Environ- mental Engineering, \\ N. E. Kruchinina \\ Dr. Eng., Head of Fac- ulty of Biotechnol- ogy and Environmental Engineering, Head of Department of Environ- mental Engineering}

Key words:

Coagulation, titaniumcontaining coagulants, suspended solids, water jet cleaning of parts.

\begin{abstract}
A B S T RACT
Setting up a circulation water supply system is a prerequisite for a modern competitive steel making company. The most frequent problem faced by steel makers includes the challenge of removing suspended solids from large volumes of wastewater. Residual concentration of suspended solids $(1-10 \mathrm{mg} / \mathrm{l})$ is the main criterion of treatment efficiency. The most difficult task is to remove particles smaller than 1-2 microns, which stay suspended for a long time. One of the biggest sources of wastewater includes the process of removing residual molding sand from machine parts by water jet surface cleaning. Apart from high concentrations of suspended solids, process wastewater have high concentrations of dissolved organic compounds and require prior treatment before it can go to municipal wastewater treatment plants. Titanium-containing coagulants are being used more and more commonly in water treatment processes due to their high efficiency and the lack of most of the drawbacks inherent in conventional coagulants. This paper compares the conventional coagulants (i.e. aluminum and iron compounds) and coagulants containing titanium salts. In addition, complex titanium-containing coagulants were tested in the actual process of removing residual molding sand from machine parts by water jet surface cleaning. The findings show that titanium tetrachloride outperforms the conventionally used aluminum sulphate and iron chloride, while the effective dose of titanium tetrachloride is on average 2.5 to 3.0 times smaller.

The obtained experimental data characterize the effect of added titanium compounds on the water treatment efficiency when conventional reagents are used. It was found that the addition $7.5 \mathrm{wt} \%$ of titanium tetrachloride to the conventional aluminum sulphate increases the treatment performance of the latter by $30 \%$. The high efficiency of titanium-containing reagents is due to specific hydrolysis effects, as well as nucleation and flocculation at the surface of hydrolysis products. The rate of sedimentation and filtration of sludges resultant from water treatment with titanium-containing coagulants significantly exceeded that reached when using conventional reagents. The use of titanium-containing reagents will enable to transfer to smaller settlers and filters, reduce the consumption of reagents and reach an enhanced treatment performance. The treated water can be reused or discharged into municipal sewage treatment plants.
\end{abstract}

\section{Introduction}

Steel making and the related industries are essential for the economics of many countries. Ore mining and beneficiation, iron and steel making, as well as machining of steel parts - all these processes affect the environment.

Mould casting is the most popular technique for making complex parts. Two types of materials are used in part casting: molding sand made with sand, clay and additives; and core sand made with quartz sand, binders and antistick coatings [1-2]. Different polymer resins, liquid glass, phenol formaldehyde and phosphate binders can be used as additives [3-5]. Shake out tables, sand- and shotblasting chambers are used for surface cleaning of parts. A recent trend in steel and mining industries is to use water jet cleaning [6-8].

Water jet cleaning is used in steel making to remove residual sand from complex parts, as well as for surface finishing before painting or coating. Water jet cleaning is a personnel-friendly and dust-free technique.

Considerable amounts of wastewater carrying sand particles, metal oxides, ore particles and binding agents (phosphates, silicates or phenol formaldehyde resins) are generated during surface finishing. Some of that wastewater can be reused after treatment [9-11]. As this practice is not widely adopted yet, most of the contaminated water is discharged into the sewer.

In most cases, however, before such wastewater can be reused or discharged, it is settled for 15 to 60 minutes so that coarse particles could be removed. At the same time, dust particles that are the result of abrasion $(<1$ $\mu \mathrm{m})$ do not settle. Coagulants containing aluminium or iron salts help intensify separation of suspended particles [12-13]. In spite of low cost and high effectiveness, these reagents have their drawbacks. Thus, aluminium salts are poorly effective at low water temperature, and iron compounds are abrasive and can cause corrosion [14]. What is gaining popularity today is titanium-containing coagulants. Researcher teams from Russia and China have proved that titanium-containing coagulants have high efficiency in water treatment applications [15-20].

\section{Objects and methods of research}

The relevance of this research study is attributed to the need to reduce the amount of clean water consumed by steel industry and to maximize the efficiency of wastewater treatment operations (which also involves removal of organic contaminants and phosphates) aimed at reduc- 
ing fines imposed by regulators and water and sewerage services providers.

This research study aims to analyze the efficiency of titanium-containing coagulants for wastewater treatment in the case of wastewater generated as a result of water jet surface cleaning of castings.

The objectives of this research study are to understand:

If titanium-containing coagulants can be used for water treatment

If added titanium compounds could enhance the efficiency of conventional coagulants.

Coagulation efficiency was analyzed with the help of a JLT 4 flocculator (VELP). Agitation time -2 minutes; flocculation time -8 minutes; sedimentation time 30 minutes.

Samples of treated water were analyzed for the concentration of suspended solids by gravimetry and using an HI 98703-02 portable turbidity meter by HANNA Instruments.

The Hach DR 2800 Portable Spectrophotometer (USA) was used to determine the concentration of iron, phenol formaldehyde, and phosphates.

The size and zeta-potential of colloid particles were analyzed with the help of the following instruments: Zetasizer Nano by Malvern and Analysette 22 NanoTec by Fritsch.

The sedimentation rate and the volume of the sediment were determined visually using measuring cups. The filtration rate was determined by putting a given amount of water through filter paper for 60 seconds.

Wastewater from the water jet cleaning facility of a machine building site in the Moscow Region was examined in the study. The as-received water had the following concentrations of contaminants: phenol formaldehyde $-12 \mathrm{mg} / \mathrm{l}$, phosphates $-27 \mathrm{mg} / \mathrm{l}$, suspended matter $718 \mathrm{mg} / \mathrm{l}$, including iron $-309 \mathrm{mg} / \mathrm{l}$; the colloid particle charge was $(-32 \mathrm{mV})$, particle size $-1-2 \mu \mathrm{m}$.

The following was used as coagulants: an aqueous solution of $\mathrm{TiCl}_{4} ; \mathrm{Al}_{2}\left(\mathrm{SO}_{4}\right)_{3} \cdot 18 \mathrm{H}_{2} \mathrm{O}$ and $\mathrm{FeCl}_{3} \cdot 6 \mathrm{H}_{2} \mathrm{O}$, as well as samples of complex coagulants containing a conventional reagent modified with titanium tetrachloride hydrolysis products. The concentration of the latter in the complex coagulant varied from 2.5 to $10.0 \mathrm{wt} \%$ (reference parameter: $\mathrm{TiO}_{2}$ ).

\section{Findings and discussion}

Fig. 1 below shows comparison data on the treatment efficiency reached when using conventional aluminium, iron and titanium containing reagents.

As is shown in the graph above, the performance of the titanium tetrachloride coagulant is comparable to that of the conventional reagents. Compared with aluminium or iron salts, it takes on average 2.5 to 3.0 times less titanium tetrachloride to reach maximum efficiency. Considering the negative charge $(-25-35 \mathrm{mV})$ at the surface of colloid particles, the coagulation mechanism can differ greatly depending on the reagent used.

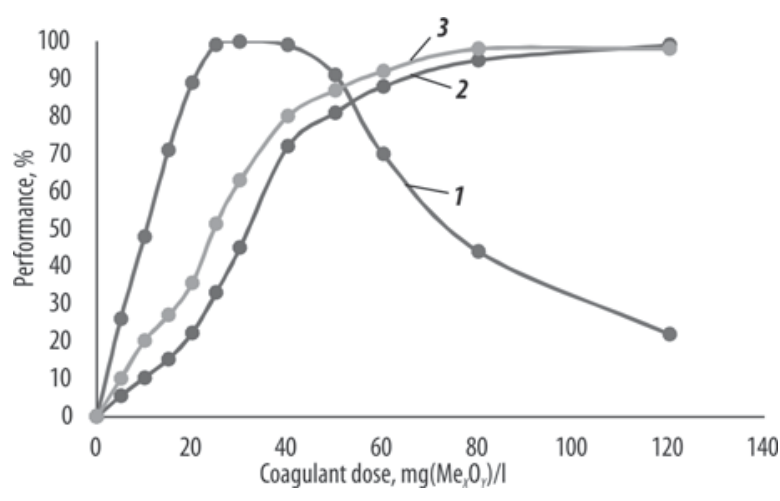

Fig. 1. Removal of suspended solids from water by coagulation: Process performance

1 - titanium chloride; 2 - aluminium sulphate;

3 - iron chloride

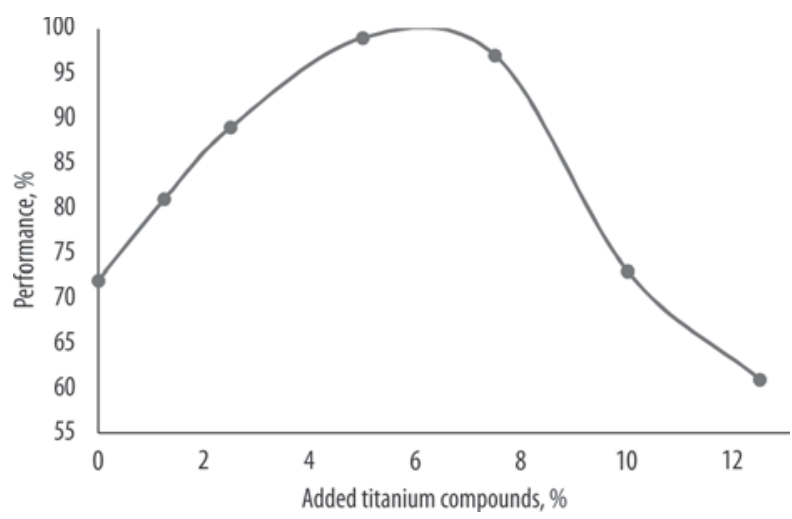

Fig. 2. Effect of added titanium compounds on the treatment performance

Thus, for aluminium and iron salts, coagulation is probably the result of neutralization occurring when negatively charged colloid particles come in contact with positively charged particles of $\mathrm{Al}$ and $\mathrm{Fe}$ hydroxides. For titanium-containing systems, it is most likely that contaminants get adsorbed by the developed surface of titanium hydrolysis products [21]. Reduced treatment efficiency occurring as a result of the dose of titanium compounds exceeding $40 \mathrm{mg} / 1$ is attributed to a growing negative charge at particle surface (zeta-potential is over - $45 \mathrm{mV}$ ) and a stabilized colloid system [22].

One knows that titanium compounds, when added to conventional coagulants, help improve the performance of the latter while saving reagents as their effective dose would be reduced [20]. As the use of iron salts as coagulants lead to water contamination with iron, aluminium sulphates were used in further experiments.

Various doses of a $1 \%$ aqueous solution of titanium tetrachloride were added to a given amount of $2 \%$ aluminium sulphate with an equivalent concentration of $\mathrm{Al}_{2} \mathrm{O}_{3}-$ $40 \mathrm{mg} / \mathrm{l}$. Fig. 2 shows how the treatment efficiency would change depending on the weight of the additive.

As can be seen from Fig. 2, addition of $7.5 \mathrm{wt} \%$ of titanium compounds leads to a 1.35 times higher performance of aluminium sulphate. For comparison: it 


\begin{tabular}{|c|c|c|c|c|c|}
\hline \multicolumn{6}{|c|}{ Residual concentrations of contaminants after coagulation } \\
\hline Contaminant & Unit & $\begin{array}{c}\text { As-received } \\
\text { water }\end{array}$ & $\begin{array}{l}\text { Aluminium } \\
\text { sulphate }\end{array}$ & $\begin{array}{l}\text { Titanium } \\
\text { chloride }\end{array}$ & $\begin{array}{c}\text { Complex } \\
\text { coagulant }\end{array}$ \\
\hline $\begin{array}{l}\text { Suspended } \\
\text { solids }\end{array}$ & \multirow{4}{*}{$\mathrm{mg} / \mathrm{l}$} & 718 & 35.9 & 10.2 & 11.4 \\
\hline Total iron & & 301 & 5.2 & 1.0 & 2.1 \\
\hline $\begin{array}{l}\text { Phosphate } \\
\text { ions }\end{array}$ & & 27 & 2.5 & 6.7 & 1.3 \\
\hline $\begin{array}{l}\text { Phenol } \\
\text { formalde- } \\
\text { hyde }\end{array}$ & & 12 & 6.4 & 2.3 & 3.1 \\
\hline
\end{tabular}

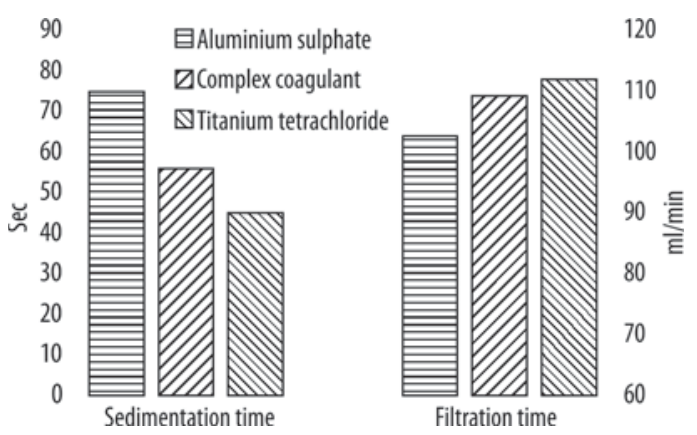

Fig. 3. Effect of added titanium compounds on the sludge filtration and sedimentation rates

took $80 \mathrm{mg} / \mathrm{l}$ of coagulant to reach the same treatment performance with aluminium sulphate. High efficiency of the complex titanium-containing coagulant is attributed to the specific hydrolysis effects that are typical of titanium (polycondensation) and a lower surface charge of the flocculates due to the presence of positively charged aluminium hydroxides and negatively charged titanium hydroxides (nucleation) [14, 23-25].

Table below shows residual concentrations of all contaminants in the water after water jetting of machine parts to remove residual molding sand when optimum doses of coagulants were used.

Table demonstrates that titanium-containing coagulants, even with smaller amounts of active components, are more efficient at removing the major contaminants from water. Considering that small amounts of titanium compounds and half as much of the key reagent are needed, the overall treatment costs are not likely to rise. A major advantage of the complex coagulant is that it is highly efficient at removing soluble organic components of molding sand. Due to this, treated wastewater can be directed to the municipal advanced water treatment facility.

The final stage of the research study included analysis of the coagulation sludge sedimentation and filtration rates. Fig. 3 shows data obtained through experiment.

Fig. 3 shows that the use of titanium tetrachloride coagulant, as well as complex titanium-containing coagulant helps intensify sludge sedimentation and filtration by $10-15 \%$ on average, which definitely speaks for the use of the above reagents. Adoption of new highperformance titanium-containing coagulants and, consequently, transfer to smaller settlers and filters will help set up a circulation water supply system and adopt the best available technology [26] by steel and machine building companies.

\section{Conclusion}

This paper examines the process of wastewater treatment in application to wastewater generated in the course of water jetting of castings in order to remove residual molding sand.

It was established that it takes 3 times more conventional coagulants (i.e. aluminium sulphate and iron chloride) to reach the same performance compared with the used of titanium-containing reagents (25 and $80 \mathrm{mg}\left(\mathrm{Me}_{X} \mathrm{O}_{Y}\right) / 1$, respectively).

It was determined that the addition of 5.0 to $7.5 \mathrm{wt} \%$ of titanium compounds helps raise the performance of aluminium sulphate by 10 to $15 \%$.

It was found that titanium tetrachloride, as well as a complex Al-Ti-containing reagent deliver an excellent water treatment performance for all the studied components (phosphates, suspended solids, iron compounds), with the consumption of the reagents needed for maximum performance being on average 1.5 to 2.0 times lower than that of conventionally used aluminium sulphate.

It was proved that titanium compounds added to aluminium sulphate help raise the sludge sedimentation and filtration rate by more than $30 \%$ compared with pure aluminium sulphate. Due to this, the complex reagent can be used with standard process equipment (for instance, in a flotation unit [27]).

Reusing the treated water will help lower the abrasion wear of the equipment due to low concentration of suspended particles in the water. Considering the effect of dilution, such treated water can be further processed at the municipal advanced water treatment facility with no disruption to its normal operation.

This research study was carried out as part of the programme supporting research projects carried out by young staff of D. Mendeleev University of Chemical Technology of Russia (Application 3-2020-013)

\section{REFERENCES}

1. Zhukovskiy S. S., Lyass A. M. Moulds and cores made of coldsetting sands. Moscow : Mashinostroenie, 1978. 224 p.

2. Gerasimov S. P., Titov A. Yu., Palachev V. A., Konovalov A. N. Technology of art casting obtaining using cold-setting mixture molds with facing ceramic layer. Tsvetnye Metally. 2015. No. 10. pp. 8-12.

3. Illarionov I. E. A scientific basis for developing core and molding sands with the help of inorganic phosphate binders and hardener powders. Liteyshchik Rossii. 2016. No. 1. pp. 16-27.

4. Evlampiev A. A., Chernyshev E. A., Grigoriev L. P. The practice of adopting the Alfa-set process. Liteynoe proizvodstvo. 2011. No. 5. pp. $17-18$. 
5. Lyutyi R. V., Guriya I. M., Shapovalova D. V., Keush D. V. Orthophosphoric acid and metal salts contained in molding sands as the basis for binder formation. Liteynoe proizvodstvo. 2013. No. 5. pp. 16-19.

6. Golovin K. A., Grigoryev G. V., Grigoryeva E. N., Pushkarev A. E. Selecting and substantiating parameters for erosion of materials by high-velocity jet. Gornyy informatsionno-analiticheskiy byulleten. 2004. No. 2. pp. 261-264.

7. Bagazeev V. K., Valiev N. G., Simisinov D. I. Physico-mechanical substantiation of rock mass jetting in hydraulic borehole mining of placers. Gornyi Zhurnal. 2015. No. 12. pp. 25-27. DOI 10.17580/gzh.2015.12.05.

8. Brenner V. A., Zhabin A. B., Shchegolevskiy M. M., Polyakov Al. V., Polyakov An. V. Optimization of water jetting techniques for mining industry. Moscow : Gornaya kniga, 2010. $343 \mathrm{p}$.

9. Matinde E., Simate G. S., Ndlovu S. Mining and metallurgical wastes: A review of recycling and re-use practices. Journal of the Southern African Institute of Mining and Metallurgy. 2018, Vol. 118. pp. 825-844.

10. Young C. A. SME Mineral Processing and Extractive Metallurgy Handbook. Society for Mining, Metallurgy \& Exploration. 2019. $2312 \mathrm{p}$.

11. Ventskel A. V., Kibirev V. I., Kuznetsov A. Yu., Turyanskiy B. V. Optimization of the circulation water supply system at Karelsky Okatysh OJSC. Obogashchenie Rud. 2008. No. 2. pp. 35-37.

12. Prakash N. B., Vimala S., Jayakaran P. Waste water treatment by coagulation and flocculation. International Journal of Engineering Science and Innovative Technology. 2014. Vol. 3. pp. 479-484.

13. Jahanshahi M., Taghizadeh M. M. Pre-sedimentation tank effects on water treatment unit operation. Environmental quality. 2018. Vol. 28. pp. 35-42.

14. Draginskiy V. L., Alekseeva L. P., Getmantsev S. V. Natural water treatment methods and coagulation. Moscow : Nauchnoe izdatelstvo. 2005. 576 p.

15. Galloux J., Chekli L., Phuntsho S., Tijing L. D., Jeong S., Zhao Y. X., Gao B. Y., Park S. H., Shon H. K. Coagulation performance and floc characteristics of polytitanium tetrachloride and titanium tetrachloride compared with ferric chloride for coal mining wastewater treatment. Separation and Purification Technology. 2015. No. 152. pp. 94-100. DOI: 10.1016/j.seppur.2015.08.009.

16. Zhao Y., Phuntsho S., Gao B. et al. Preparation and Characterization of Novel Polytitanium Tetrachloride Coagulant for Water Purification. Environmental Science \& Technology. 2013. Vol. 47. pp. 12966-12975. DOI: 10.1021/es402708v.

17. Zhao Y. X., Gao B. Y., Zhang G. Z., Qi Q. B., Wang Y., Phuntsho S., Kim J.-H., Shon H. K., Yue Q. Y., Li Q. Co- agulation and sludge recovery using titanium tetrachloride as coagulant for real water treatment: A comparison against traditional aluminum and iron salts. Separation and Purification Technology. 2014. Vol. 130. pp. 19-27. DOI: 10.1016/j.seppur. 2014.04.015.

18. Kyeong-Jun Jeon, Johng-Hwa Ahn. Evaluation of titanium tetrachloride and polytitanium tetrachloride to remove phosphorus from wastewater. Separation and Purification Technology. 2018. Vol. 197. pp. 197-201.

19. Zhao Y., Gao B., Shon H. Floc characteristics of titanium tetrachloride $\left(\mathrm{TiCl}_{4}\right)$ compared with aluminum and iron saltsin humic acid-kaolin synthetic water treatment. Separation and Purification Technology. 2011. Vol. 81. pp. 332-338. DOI: 10.1016/j.seppur.2014.12.043

20. Kuzin E. N., Averina Yu. M., Kurbatov A. Yu., Sakharov P. A. Wastewater treatment in the electroplating industry using composite coagulants-reducers. Tsvetnye Metally. Moscow, 2019. No. 10. pp. 91-96.

21. Shabanova N. A., Popov V. V., Sarkisov P. D. The chemistry and technology of nanodispersed oxides. Learner's guide. Moscow : IKTs "Akademkniga". 2007. 309 p.

22. Izmaylova N. L., Lorentsson A. V. Understanding the hydrolysis of diluted aqueous solutions of $\mathrm{TiOSO}_{4} \cdot 2 \mathrm{H}_{2} \mathrm{O}$ and $\mathrm{TiCl}_{4}$ and electrosurface properties of the hydrolysis products. Proceedings of the $6^{\text {th }}$ Russian National Conference among Young Researchers and Post- and Undergraduate Students with International Participants “Mendeleev-2012”. Saint Petersburg : Izdatelstvo Solo, 2012. pp. 205-207.

23. Wang T.-H., Navarrete-López A. M., Li S., Dixon D. A., Gole J. L. Hydrolysis of $\mathrm{TiCl}_{4}$ : Initial steps in the production of $\mathrm{TiO}_{2}$. Journal of Physical Chemistry A. 2010. Vol. 114 (28). pp. 7561-7570. DOI: 10.1021/jp102020h.

24. Shon H., Vigneswaran S., Kandasamy J., Zareie M., Kim J., Cho D., Kim J. H. Preparation and characterization of titanium dioxide $\left(\mathrm{TiO}_{2}\right)$ from sludge produced by $\mathrm{TiCl}_{4}$ flocculation with $\mathrm{FeCl}_{3}, \mathrm{Al}_{2}\left(\mathrm{SO}_{4}\right)_{3}$ and $\mathrm{Ca}(\mathrm{OH})_{2}$ coagulantaids in wastewater. Separation Science and Technology. 2009. 44. pp. 1525-1543. DOI: 10.1080/01496390902775810.

25. Shon H., Vigneswaran S., Kim I.S. Preparation of Titanium Dioxide $\left(\mathrm{TiO}_{2}\right)$ from Sludge Produced by Titanium Tetrachloride $\left(\mathrm{TiCl}_{4}\right)$ Flocculation of Wastewater. Environmental Science \& Technology. 2007. Vol. 41. pp. 1372-1377. DOI: 10.1021/es062062g.

26. Butorina I. V., Butorina M. V. Issues of implementing the best available technologies in the steel industry of the Russian Federation. Chernye Metally. 2019. No. 1. pp. 43-48.

27. Kolesnikov A. V., Savelyev D. S., Kolesnikov V. A., Dadydkova T. V. Extraction of highly dispersed titanium dioxide $\mathrm{TiO}_{2}$ from aqueous electrolyte solutions by electroflotation. Steklo $i$ keramika. 2018. No. 6. pp. 32-36. 